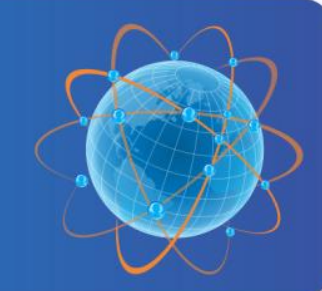

\title{
Pragmatisme Partai Islam Di Indonesia: Pendekatan Tindakan Sosial
}

Authors : Ari Ganjar Herdiansah

Published by : Departemen of Sociology, Faculty of Social and Political Science, Universitas Padjadjaran

Accepted : April 2017; Approved : May 2017

Sosiogobal: Jurnal Pemikiran dan Penelitian Sosiologi is the Department of Sociology, Faculty of Social and Political Science, Universitas Padjadjaran flagship journal. The Sosioglobal journal founded in 2016 with the mission to publish original works of interest to the discipline of sociology in general, sociological thinking, new theoretical developments, results of research that enhance understanding of fundamental social processes, and methodological innovations. We are welcome a research article, working paper, theoretical/conceptual and methodological review to submit to our journal. In addition, we are accept relevant book review that currently publish and enrich sociological perspectives. Please submit article to http://jurnal.unpad.ac.id/sosioglobal

To cite this article :

Herdiansah, Ari G.2017.Pragmatisme Partai Islam Di Indonesia: Pendekatan Tindakan Sosial.Sosioglobal : Jurnal Pemikiran dan Penelitian Sosiologi 1(2):152-167. 


\title{
PRAGMATISME PARTAI ISLAM DI INDONESIA: PENDEKATAN TINDAKAN SOSIAL
}

\author{
Ari Ganjar Herdiansah ${ }^{1}$ \\ ${ }^{1}$. Departemen Ilmu Politik, Fakultas Ilmu Sosial dan Ilmu Politik, Universitas Padjadjaran \\ ari.ganjar@unpad.ac.id
}

\begin{abstract}
ABSTRAK
Partai-partai Islam di Indonesia dianggap telah jauh bergeser pada skema tindakan pragmatis, meninggalkan tindakan-tindakan ideologis dalam berbagai kebijakan politiknya. Karenanya, partai Islam dianggap tidak lagi memiliki identitas yang jelas setelah mereka memiliki platform yang tidak berbeda dengan partai-partai nasionalis sekuler. Artikel ini menggali lebih jauh konsep pragmatisme partai Islam dari pendekatan tindakan sosial. Dengan menyandang ideologi Islam, partai-partai Islam dituntut untuk melahirkan kebijakan dan tindakan yang sesuai dengan semangat spiritual keislaman. Tetapi di saat yang sama, sebagai organisasi partai mereka juga dituntut profesional dan fleksibel dalam rangka meraih tujuan-tujuan politiknya. Mereka berada di antara dua ranah, yang satu penuh dengan dimensi moralitas, yang satu lagi terkadang bersifat amoral. Di Indonesia, partai Islam senantiasa beradaptasi dengan lingkungan dan sistem politik demokratis, sehingga menuntut mereka menjadi pragmatis, meskipun identitas dan isu-isu keagamaan masih menjadi persoalan pokok bagi eksistensi mereka.
\end{abstract}

Kata kunci : partai Islam, pragmatisme, tindakan sosial, demokrasi

\begin{abstract}
Islamic parties in Indonesia are thought to have shifted to pragmatism, abandoning ideological principle in their various policies. Therefore, the Islamic parties are perceived to have no clear identity as they platform is indistinguishable from secular counterparts. This article explores the concept of Islamic party pragmatism from social action approach. With putting Islam or Muslim identity as the primary symbol, Islamic parties were demanded to produce policies and measures by the Islamic spirit. But on the other side, as a party organization, they were also required to be professional and flexible to achieve their political goals. They are between two domains, one full of morality dimensions, the other one sometimes in the less clear morality sphere. In Indonesia, Islamic parties are constantly adapting to the democratic environment and political systems, demanding them to be pragmatic, although identities and religious issues were still a central theme for their existence.
\end{abstract}

Keywords : Islamic party, pragmatism, social action, democracy 


\section{PENDAHULUAN}

Salah satu pembahasan yang menarik tentang demokratisasi di Indonesia adalah eksistensi partai berbasis Islam. Pertanyaannya apakah partai-partai berbasis Islam mampu mempertahankan identitasnya di tengah-tengah kompetisi politik yang terkadang moralitas tidak relevan? Banyak pihak yang memprediksi bahwa partai-partai berbasis Islam tidak akan bertahan lama dalam kompetisi pemilu karena tindakan-tindakan pragmatis yang mereka tunjukkan telah melemahkan identitas dan positioning-nya. Meskipun begitu, kenaikan perolehan suara partaipartai berbasis Islam di Indonesia pada pemilu 2014 yang secara kolektif meraih 33 persen dibanding 29 persen pada pemilu 2009 justru menunjukkan bahwa mereka mampu meningkatkan kembali kinerja elektoralnya.

Artikel ini tidak bertujuan menjelaskan mengapa partai-partai berbasis Islam mampu meningkatkan kembali perolehan suara pada pemilu 2014. Tetapi, melesetnya prediksi tentang kemunduran partai-partai berbasis Islam, seperti yang telah diutarakan oleh Tanuwidjaja (2010) misalnya, memantik pertanyaan kritis tentang konsep pragmatisme yang seringkali diterapkan kepada partai-partai Islam. Istilah pragmatisme cenderung disematkan kepada mereka dengan asumsi telah terjadi pergeseran karakter partai dari yang semula berbasis ideologi menjadi partai yang condong memprioritaskan aspek-aspek praktis, materi, dan kepentingan elitenya. Tanpa bermaksud menyangkal fakta-fakta yang menyebabkan asumsi tersebut terbentuk, artikel ini menggali konsep pragmatisme sebagai suatu tindakan sosial dan melihat bagaimana konsekuensinya ketika diterapkan pada konteks partai berbasis agama (Islam) di Indonesia.

Pembahasan artikel ini dibagi menjadi tiga bagian. Bagian pertama membahas kajian konseptual tentang skema tindakan sosial untuk menemukan penjelasan mengenai tindakan pragmatis atau pragmatisme. Pemikiran dari Max Weber dijadikan sebagai landasan dalam mengelaborasikan lebih lanjut konsepsi skema tindakan sosial. Bagian kedua membahas pengertian dan karakteristik partai Islam untuk lebih memahami bagaimana skema tindakan sosial dapat diterapkan pada partai Islam. Pada bagian ketiga, pembahasan diarahkan pada kajian-kajian empiris yang menunjukkan dinamika partai Islam selama berkiprah dalam kompetisi demokrasi di Indonesia. Inti argumen dari artikel ini menyatakan bahwa partai Islam merupakan organisasi politik yang bekerja dalam sistem sosial yang mengalami modernisasi. Mereka dicirikan secara khas oleh orientasi kepentingan yang kuat, tetapi tetap berupaya mempertahankan identitas dan positioning-nya dalam persaingan elektoral. Keadaan tersebut menutut partai Islam untuk mempertimbangkan tindakan-tindakan yang rasional, terutama pada ranah tindakan pragmatis dan ideologis. 


\section{METODE PENELITIAN}

Analisis dalam artikel ini dibangun berdasarkan studi kepustakaan. Pembahasan difokuskan pada konsep-konsep tindakan sosial untuk mendapatkan pemahaman tentang posisi tindakan pragmatis di dalam skema tindakan sosial. Karena keterbatasan ruang dalam artikel ini, pembahasan konsep dibatasi sehingga lebih menyoroti pada kategorisasi tindakan-tindakan sosial untuk menemukan konsepsi rasionalitas dan tindakan pragmatis yang sesuai dengan konteks pendekatan organisasi politik, terutama partai politik. Pada sisi yang lain, pembahasan konseptual tentang ciri-ciri atau karakter partai politik Islam juga ditempatkan dalam upaya membangun titik persilangan antara tindakan pragmatis dan karakter organisasi partai Islam. Untuk menjelaskan argumen-argumen yang diajukan, berbagai studi empiris yang berkenaan dengan dinamika politik partai Islam pasca Orde Baru disajikan sebagai bukti-bukti atau indikasiindikasi pendukung.

\section{KERANGKA TEORI/KONSEP}

\section{Tindakan Pragmatis dalam Skema Tindakan Sosial}

Karya terkemuka pada abad ke-20 yang membahas tindakan sosial dapat dilihat pada eksemplar utama karya Max Weber dan Ludwig von Mises. Konsep tindakan sosial Weber berangkat dari suatu pertanyaan sederhana tentang apa yang menyebabkan kapitalisme dapat berkembang secara 'sempurna' di Barat tetapi tidak di wilayah lainnya? Salah satu upaya dalam penjelasan atas pertanyaan tersebut terdapat dalam rumusan tipe ideal tentang orientasi tindakan yang membandingkan antara fenomena yang terjadi di Barat dan non-Barat. Tipe ideal tindakan sosial merupakan abstraksi yang dijadikan sebagai alat untuk melihat kasus-kasus nyata yang kemudian dibandingkan dengan kategori tindakan sosial.

Weber membagi tindakan sosial menjadi empat jenis skema fundamental, pertama rasional instrumental (zpeckrational), yakni ekspektasi atas perilaku obyek dalam lingkungan atau terhadap orang lain, di mana ekspektasi tersebut digunakan sebagai kondisi atau alat untuk mencapai tujuan-tujuan aktor yang rasionalitas atau penuh perhitungan. Kedua, rasional nilai (wertrational) yakni tindakan yang berasal dari keyakninan yang disadari berdasarkan nilai yang terkandung dalam bentuk perilaku etika, estetika, agama, dan sebagainya. Tindakan tersebut tidak bergantung pada kesuksesan tujuan, tetapi lebih pada pemenuhan nilai yang acuannya terdapat pada kepuasan pelaku atau pengakuan dari lingkungan sosialnya terhadap pelaku. Ketiga, afektual, yaitu tindakan yang didorong oleh kondisi perasaan atau emosi pelaku. Pada jenis tindakan ini, orang seringkali tidak memikirkan konsekuensi selanjutnya. Keempat, tradisional atau tindakan yang dikendalikan oleh tradisi, sesuatu yang biasa dilakukan sebelumnya (Callahan 2007).

154 | SGSIOGLLBAL : Jurnal Pemikiran dan Penelitian Sasiologi, Vol. I, №. Z, Juni 2017 
Dari keempat susunan tindakan sosial di atas, Weber menunjukkan terdapat dua kategori tindakan yang mencirikan peradaban Barat yang mampu membangun kapitalisme dibandingkan dengan peradaban lainnya. Dua tindakan pertama, yaitu rasional instrumental dan rasional nilai digolongkan pada kategori tindakan rasional yang menjadi ciri perkembangan peradaban Barat (ideal). Sementara tindakan afektual dan tindakan tradisional dipertimbangkan sebagai tindakan yang di luar rasionalitas yang menggejala para peradaban non-Barat. Namun, Mises menolak kategorisasi semacam itu. Menurutnya, semua tindakan sosial adalah rasional karena pasti memiliki tujuan yaitu memenuhi hasrat dari pelaku yang bertindak. Karena tidak ada standar yang dapat mengukur kepuasan seorang pelaku atas tindakannya, seseorang tidak dapat menilai tindakan orang lain berdasarkan ukuran dirinya. Tindakan, menurut Mises, tidak terlepas dari proses berpikir pelaku. Dengan kata lain tidak ada tindakan tanpa berpikir (Callahan 2007).

Dalam praktiknya, tidak ada tindakan yang murni mewakili salah satu jenis dari skema tindakan Weber. Misalnya, asumsi tindakan tradisional menempatkan pelaku yang mengikuti arahan tradisi tanpa menghadirkan proses pemaknaan terhadap situasi. Asumsi tersebut sulit untuk diterima karena setiap manusia melakukan tindakan sosial dalam keadaan sadar untuk merespons stimulus-stimulus terhadap dirinya. Suatu tindakan yang dianggap tradisional juga mengandung sisi nilai, rasional, dan afektual yang masing-masing derajatnya tergantung pada keadaan atau keinginan pelaku. Misalnya menjadikan agama sebagai ideologi partai politik sebagaimana dilakukan oleh para pendahulunya, tindakan tersebut dapat mengandung motivasi lainnya seperti ingin meraih dukungan suara dan memenangkan pemilu (rasional), memenuhi kewajiban agama (nilai), dan meraih kepuasan batin (afektual). Demikian pula pada tindakan yang dianggap rasional, misalnya seorang kandidat berupaya memenangkan pemilu, barangkali juga didorong oleh tuntutan tradisi klan untuk menjadi pemimpin (tradisional), memenuhi kepuasan (afektual), dan mencapai prestise (rasional-nilai).

Meskipun telah dianggap usang dan mendapatkan banyak kritik, salah satunya karena masalah Eurocentrism, pendekatan Weber tentang tipe ideal tindakan sosial masih signifikan ketika dikaitkan dengan tipe ideal pada konteks birokratisasi pada masyarakat modern. Gejala utama pada masyarakat modern adalah birokratisasi, yaitu proses rasionalisasi dalam seluruh aspek organisasi kehidupan manusia. Menurut Weber, masyarakat modern telah dikendalikan seperti halnya biro atau kantor yang dikelola dengan berbagai aturan administrasi, dijalankan oleh orang-orang yang memiliki keahlian dan keterampilan tinggi, pembagian kerja yang spesifik, mengutamakan impersonalitas, dan kewenangan yang terstruktur secara hierarkis. Prinsipprinsip tersebut berorientasi untuk menyediakan sistem yang menjamin efisiensi dan pemenuhan tujuan, di mana tindakan rasional menjadi pilihan yang ideal (Zeitlin 1994). 
Parsons (2005) yang memberikan analisis terhadap perkembangan modernisasi telah mendefinisikan tindakan sosial dalam nuansa yang mengedepankan aspek rasionalitas. Ia menyatakan bahwa tindakan sosial dilakukan oleh pelaku maupun kelompok karena motivasi mencapai tujuan sebagaimana yang dimaknai dalam sistem budaya yang berlaku. Munculnya tindakan sosial tidak terlepas dari konteks situasi yang mungkin terdapat rintangan ataupun kemudahan yang dilalui oleh pelaku. Aspek-aspek normatif pada sistem sosial dapat menjadi pertimbangan bagi pelaku dalam menentukan bentuk tindakannya. Namun, ketika penjelasan Parsons cenderung melihat struktur sebagai faktor determinan tindakan sosial, Cuff, dkk (2006) berpendapat bahwa tindakan rasional juga menuntut penafsiran pelaku karena dilakukan berdasarkan perhitungan yang matang dan bersandar pada informasi yang dapat dipertanggung jawabkan keakuratannya.

Dalam kehidupan sehari-hari, tindakan rasional yang mengedepankan perhitungan dan informasi yang akurat tidak selalu praktis. Individu atau kelompok seringkali berhadapan dengan situasi yang kurang memungkinkan mereka dapat mempergunakan pertimbangan-pertimbangan teoretis. Dalam konteks inilah tindakan pragmatis menemukan relevansinya. Menurut Ritzer (2005), pragmatisme merujuk pada tindakan realistis dalam menghadapi situasi praktis di mana panduan-panduan teoretis tidak begitu berguna. Demikian pula penjelasan Sharrock, dkk (2003) tentang tindakan pragmatis bahwa kriteria tindakan dinilai dari aspek apakah tindakan pelaku efektif mengatasi masalah? Bukan berdasarkan pada standar penilaian kebenaran yang abstrak. Tindakan pragmatis atau pragmatisme menganggap makna tentang kebenaran, kebebasan, dan baik-buruk tidak terlalu penting karena berdasarkan pengalaman pelaku konsep-konsep tersebut tidak berkaitan dengan pemecahan masalah. Pragmatisme mengedepankan suatu cara pandang tentang tindakan yang harus dilihat dari dampak-dampak praktis, yaitu mencapai tujuan atau mengatasi masalah yang dihadapi pelaku.

Dalam pembahasan publik, tindakan pragmatis seringkali dihadapkan dengan tindakan ideologis. Hal tersebut juga sejalan dengan wacana modernisme di mana ideologi condong ditempatkan secara berseberangan dengan rasionalitas. Seperti pandangan Marxis yang menganggap ideologi sebagai sistem gagasan yang mengaburkan kesadaran masyarakat dari kenyataan sebenarnya. Dalam sistem sosial, ideologi merupakan hubungan-hubungan sosial yang terbangun akibat persamaan bentuk-bentuk pengetahuan, pemikiran, atau pemahaman. Karenanya, ideologi dapat diperlakukan sebagai perekat di antara para aktor sehingga suatu kelompok dapat memelihara kohesivitasnya. Dengan ideologi, setiap individu tampil seolah-olah satu entitas (unified) dan bertindak sebagai subyek yang dapat mengendalikan perilakunya berdasarkan prinsip-prinsip yang diyakininya (Tew 2002). 
Berbeda dengan tindakan pragmatis mengabaikan panduan-panduan teoretis, tindakan ideologis justru mengedepankan aturan, prinsip, dan nilai-nilai baik yang diyakini oleh pelaku maupun yang berlaku dalam kelompok. Namun, bukan berarti tindakan ideologis tidak sejalan dengan rasionalitas. Tindakan ideologis masih berada dalam koridor rasionalitas karena mereka hendak mencapai tujuan tertentu ketika melakukan tindakannya (Layder 2006). Tindakan ideologis lebih sesuai digambarkan dalam kategori tindakan rasionalitas-nilai, sementara tindakan pragmatis lebih merepresentasikan rasionalitas-tujuan. Tetapi, kembali pada skema empat tindakan dari Weber, bahwa setiap jenis tindakan tidak dapat dipastikan terbebas dari unsur-unsur yang lain. Pengkategorian tersebut juga hanya dapat dipahami dalam konteks analisis dan sulit ditemukan secara utuh dalam dunia nyata.

\section{PEMBAHASAN}

\section{Partai Islam dalam Skema Tindakan Sosial}

Dalam upaya menelaah pendekatan partai Islam dalam skema tindakan sosial, perlu dijabarkan terlebih dulu pembahasan tentang pengertian dan karakteristik partai Islam itu sendiri. Karena pola tindakan sangat terkait dengan setidaknya dua hal, yakni status dan peran pelaku di satu sisi dan situasi atau keadaan di sisi lain. Di antara kedua hal tersebut berlangsung hubungan saling mempengaruhi; bagaimana pelaku berkehendak untuk menafsirkan situasi dan memutuskan bentuk tindakan, serta bagaimana situasi atau keadaan menentukan persepsi pelaku. Karena itu, tindakan merupakan suatu aspek yang dinamis dalam suatu proses interaksi pelaku dengan lingkungan baik fisik maupun sosial yang dihadapinya.

Institusi dasar dari partai Islam adalah partai politik. Karenanya, definisi tentang partai Islam tidak mungkin dapat dikonstruksi tanpa mengambil ciri-ciri substansial partai politik. Dalam pengertian yang umum, partai politik merupakan organisasi yang bertujuan memperoleh kendali atas pemerintahan melalui mekanisme kompetisi yang menempatkan kader-kadernya di lembaga legislatif dan eksekutif (Heywood 2002). Partai politik bersifat independen, didirikan oleh warga negara dengan sasaran memenangkan pemilu supaya dapat mengendalikan kekuasaan pemerintah melalui penguasaan posisi-posisi pejabat publik dan organisasi pemerintahan (Huckshorn 1984).

Ciri umum lainnya dari partai politik adalah perannya yang sentral dalam sistem politik demokratis, dengan pengecualian di beberapa negara seperti Republik Rakyat Tiongkok. Partai politik berperan menjembatani warga negara dengan pemerintah sebagai bagian dari mekanisme kedaulatan rakyat, di mana pemerintahan sedapat mungkin dapat dikendalikan oleh rakyatnya (Asayesh, Halim, \& Shojaei 2011). Namun, komposisi rakyat tidaklah homogen tetapi terdiri 
dari berbagai kelompok yang terdiferensiasi berdasarkan ideologi, kelas, ras, daerah, agama, etnik, dan profesi. Di beberapa negara dengan heterogenitas yang tinggi, seperti Indonesia, komposisi tersebut bisa sangat beragam dan kompleks. Partai politik berfungsi menjadi saluran aspirasi dan kepentingan dari segmen-segmen tertentu atau bahkan segmen yang luas yang ada di masyarakat. Mereka berjuang untuk mempengaruhi kebijakan pemerintah dengan cara-cara yang konstitusional. Dalam perjuangannya itu, mereka harus terlibat dalam persaingan atau/dan kerja sama baik dengan sesama partai politik maupun dengan institusi-institusi lainnya. Mereka tidak terlepas dari suatu dictum bahwa tidak ada kawan atau lawan yang abadi, tetapi yang ada adalah kepentingan yang abadi.

Di banyak negara berpenduduk mayoritas Muslim, partai Islam hadir di tengah-tengah menguatnya institusi negara-bangsa yang modern. Sebagian dari partai Islam justru muncul karena merespons gejala sekulerisasi yang semakin menjauhkan aspek-aspek agama dari kehidupan sosial politik. Mereka merupakan bagian dari instrumen kebangkitan gerakan keagamaan dalam perubahan sosial yang terseret modernisasi dan westernisasi. Tetapi sebagian lainnya muncul untuk memperkuat rezim yang otoriter atau menciptakan tatanan politik teokrasi (Mosheni and Wilcox 2012). Karena karakteristik partai Islam sangat beragam dan tergantung pada situasi politik yang berlangsung di negaranya, mereka tidak mungkin dapat dipahami sebagai fenomena yang tunggal. Sebagaimana karakteristik politik Islam itu sendiri yang dipengaruhi oleh situasi dan konteks lokal, demikian pula karakter partai Islam terbentuk sesuai responsnya terhadap situasi yang ingin mereka atasi. Di Yaman, misalnya, Partai Al-Islah terbentuk berdasarkan nilai-nilai keagamaan dan kesukuan dengan dimensi kepentingan regional. Mereka membawa misi untuk merekatkan bangsanya dengan kepentingan Arab Saudi dan sempat menjadi kekuatan oposisi bagi pemerintahan. Di Palestina, Partai Hamas memiliki sayap pasukan militer Brigade Al-Qassam untuk mempertahankan diri dari ancaman militer Israel.

Partai Islam yang pada konteks tertentu juga merupakan bagian dari gerakan Islam yang menghadapi dampak-dampak dari modernisasi dan globalisasi politik dalam berbagai cara. Setidaknya terdapat tiga respons yang dapat dipetakan secara umum. Pertama, gerakan Islam yang mengadopsi demokrasi sebagai sistem budaya. Mereka menolak pendekatan eksklusif Barat tentang demokrasi dan menafsirkan demokrasi melalui perspektif Islam, misalnya menganggap konsep syura yang cocok dengan demokrasi deliberatif. Dengan begitu prinsip-prinsip demokrasi dinilai sejalan dengan budaya, sejarah, nilai-nilai lokal, dan ketika digunakan dalam berpolitik tidak melanggar syariah. Kedua, gerakan Islam yang menganggap mendukung atau menggunakan demokrasi sebagai pilihan strategis dalam rangka mencapai tujuan-tujuannya. 
Jenis gerakan seperti ini biasanya terjadi di negara-negara yang menyelenggarakan pemilu secara relatif terbuka dan adil. Sistem demokrasi yang telah menjadi konsensus kebenaran sistem politik digunakan kelompok Islamis untuk meraih dukungan legitimasi dari rakyatnya. Ketiga, gerakan Islam yang menolak demokrasi baik secara substansial maupun metode. Mereka memandang demokrasi sebagai sistem yang tidak terdapat dalam ajaran Islam dan diimpor dari kebudayaan Barat yang kufur (Abed dkk. 1993; Ba-Yunus \& Donnan 2002; Tibi 2002).

Pada konteks Indonesia, respons terhadap demokrasi dari gerakan Islam juga beragam dan secara garis besar dikelompokkan ke dalam tiga golongan. Pertama, golongan formalis yang memilih menghendaki Islam dijadikan ideologi partai secara resmi. Mereka memperjuangkan nilai-nilai Islam melalui jalur politik dan berpartisipasi dalam pemilu. Kategori ini diwakili oleh partai-partai berideologi Islam antara lain PPP, PKS, dan PBB. Kedua, golongan substansialis yang menjadikan nilai-nilai Islam sebagai substansi kehidupan sosial politik, tetapi menolak formalisasi Islam pada negara dan pemerintahan. Pada ranah partai politik mereka diwakili oleh PAN dan PKB. Ketiga, golongan sekuler yang menolak inklusi agama (Islam) dalam kehidupan negara dan sistem pemerintahan, serta berupaya memisahkan domain negara dari agama. Mereka menganggap adopsi agama dalam kehidupan politik dan pemerintahan tidak hanya menggerus kualitas kehidupan bernegara, tetapi juga akan menurunkan makna beragama bagi warganya. Cara pandang demikian tidak populer karena di berbagai organisasi masyarakat Islam yang menjadi perantara antara umat Islam dan pemerintah masih didominasi oleh kelompok konservatif. Beberapa tokoh besar baik dari NU maupun Muhammadiyah yang condong pada cara pandang sekuleris, seperti Abdurrahman Wahid dan Syafii Maarif, setidaknya menjadi simbol kekuatan intelektual golongan ini. Sementara para intelektual muda yang mengemban visi Islam sekuler, seperti Luthfie Asyaukanie dan Ulil Absar Abdala bergabung dalam organisasi Jaringan Islam Liberal (JIL) (Mashad 2008; van Bruinessen 2013).

Keragaman visi gerakan Islam mempengaruhi definisi partai Islam di Indonesia yang tidak mudah diuraikan secara pasti. Dari berbagai pengertian, dapat diambil beberapa kesimpulan umum, antara lain bahwa partai Islam adalah partai yang menggunakan label Islam tetapi perjuangan sebenarnya adalah terutama untuk kepentingan umat Islam tanpa mengesampingkan kepentingan non-Muslim, atau tidak menggunakan label Islam, programnya juga untuk kepentingan semua penduduk tetapi konstituen utamanya berasal dari umat Islam (The Indonesian Institute 2009). Sementara, Yulianto (Inayatullah 2009) membagi entitas partai Islam ke dalam dua konsepsi. Pertama, partai yang memiliki asas kepartaian Islam dengan kepemimpinan di bawah kendali orang-orang yang tidak diragukan keislamannya dan mengusung simbol-simbol keislaman dari tanda sampai ke jargon-jargon politik. Partai-partai 
yang teridentifikasi dengan karakteristik tersebut antara lain PPP, PKS, dan PBB. Kedua, partai yang secara asas, simbol, jargon, dan perilaku keseharian amat jauh dari warna Islam tetapi secara kepemimpinan di bawah kendali orang-orang beridentitas keislaman. Konstituen utama partaipartai tersebut biasanya berasal dari umat Islam dan ormas keagamaan tertentu, seperti yang ditunjukkan oleh PKB dan PAN.

Uraian di atas menunjukkan bahwa partai Islam merupakan organisasi politik yang bertujuan mempengaruhi kebijakan pemerintah melalui penguasaan jabatan-jabatan publik di lembaga eksekutif dan legislatif. Mereka harus bersaing dalam kompetisi pemilu yang ketat, di mana dukungan suara yang massif merupakan kunci keberhasilan kemenangan. Partai Islam juga merupakan organisasi yang sarat dengan orientasi kepentingan. Bentuk kepentingan yang diperjuangkannya merupakan hasil kontestasi internal dari para pelaku, baik dari kalangan elite, aktivis, atau kader biasa. Dalam rangka mempertahankan keberadaannya sebagai pihak yang dapat mempengaruhi atau mengendalikan kekuasaan negara, partai Islam mau tidak mau harus berkompromi, bekerja sama, terlibat dalam persaingan dan bahkan konflik dengan partai atau institusi lainnya. Di sinilah partai Islam dituntut untuk bersifat lentur dan strategis. Mereka seringkali harus berkompromi dengan situasi, mengorbankan satu kepentingan untuk kepentingan yang lain. Di sisi lain, partai Islam juga mengemban simbol, nilai, dan norma Islam, serta harapan atau kepentingan dari konstituen utamanya yaitu kelompok-kelompok Islam. Mereka perlu menjunjung tinggi prinsip-prinsip yang terkandung dalam ajaran Islam, sebagaimana yang mereka maknai, dalam memutuskan suatu kebijakan atau tindakan politik. Dalam skema tindakan sosial, partai Islam dituntut agar dapat merespons situasi secara strategis dan rasional yaitu menggunakan pendekatan pragmatis ketika situasi menuntut demikian dan ideologis demi mempertahankan eksistensi dan positioning-nya, atau mengkombinasikan keduanya apabila pelaku mampu memberikan penafsiran yang rasional bagi pendukungnya.

\section{Partai Islam dalam Kontestasi Politik di Indonesia: Pragmatisme Vs. Ideologi}

Setelah era reformasi berjalan, partai-partai Islam tumbuh subur dan turut menyemarakkan pesta demokrasi di 1999. Sekitar 50 partai politik berbasis Islam berdiri seiring diberlakukannya perubahan undang-undang politik yang memberikan ruang kebebasan bagi warga untuk mendirikan partai baru sesuai dengan pilihan ideologinya. Namun, hanya terdapat 17 partai berbasis Islam yang mendapatkan kelulusan untuk ikut serta pada pemilu 1999. Pada masa itu, seluruh partai Islam mendapatkan 37,42 persen suara yang menggambarkan pemilih partai Islam cukup signifikan. 
Bangkitnya partai-partai Islam dalam pemilu menandakan berlangsungnya reorganisasi kekuatan kelompok-kelompok Islam yang menghubungkan partai Islam, komunitas Muslim, organisasi Islam, dan organisasi-organisasi paramiliter. Mereka berupaya untuk memperkuat pengaruh Islam dalam ruang sosial dan politik di masyarakat ketika dominasi rezim Orde Baru memudar (Jati 2013). Partai-partai berbasis Islam tampil dengan simbol-simbol Islam yang kuat. Wacana tentang pentingnya menerapkan prinsip Islam sebagai solusi atas krisis multi dimensi menjadi topik yang senantiasa mereka kemukakan. Sebagian partai Islam, yakni PPP dan PBB, bahkan berusaha menghidupkan kembali Piagam Jakarta dengan kalimat kunci "dengan kewajiban menjalankan syariat Islam bagi pemeluknya" (Hasan 2008). Sekilas, tindakan-tindakan tersebut terjadi karena penuh dengan dorongan ideologis, di mana partai-partai Islam berupaya menerapkan prinsip dan simbol Islam ke dalam tatanan kehidupan politik dan pemerintahan.

Namun, berdasarkan skema tindakan sosial faktor dan karakteristik dari situasi dan pelaku yang mendorong tindakan-tindakan yang dianggap ideologis itu harus juga dipertimbangkan. Kekosongan dominasi kekuasaan di ruang sosial dan politik menyebabkan tiap-tiap kelompok yang memiliki modal identitas politik yang kuat berupaya mengambil alih dominasi kekuasaan. Partai-partai berbasis Islam umumnya didirikan oleh tokoh-tokoh yang memiliki ikatan kuat dengan organisasi Islam besar, seperti PKB yang dekat dengan NU dan PAN yang identik dengan Muhammadiyah. Pemberlakuan sistem pemilu yang adil dalam suasana reformasi menjadi ajang bagi partai-partai untuk menunjukkan identitas dan positioning-nya demi menjangkau pemilih yang memiliki visi ideologi atau identitas yang sama. Krisis ekonomi yang parah juga menyebabkan sebagian masyarakat tidak lagi percaya pada sistem yang sudah ada, di mana keadaan tersebut menjadi aspek yang dimanfaatkan oleh partai-partai untuk menawarkan sistem alternatif yang kemudian menjadi potensi modal untuk meraup suara.

Asumsi bahwa tindakan partai-partai berbasis Islam condong pada tindakan ideologis perlu mendapatkan kritik, sebab di sisi lain mereka juga melakukan tindakan-tindakan yang dapat dianggap pragmatis. Misalnya dalam pembahasan tentang Piagam Jakarta, tidak semua partai berbasis Islam setuju dengan pemberlakuan syariat bagi golongan Muslim di Indonesia, terutama PKB dan PAN. Partai Keadilan (PK) yang notabene merupakan partai Islam justru menolak usulan tersebut dengan alasan tidak sependapat dengan formalisasi syariah. Di ranah politik pemerintahan, setelah pemerintahan Abdurrahman Wahid-Megawati terbentuk hampir semua partai berbasis Islam turut serta dalam kabinet. Ketika Abdurrahman Wahid digulingkan oleh kekuatan parlemen pada 2001, Hamzah Haz (PPP) menjadi wakil presiden mendampingi Megawati. Padahal dalam penentuan presiden di MPR pada 1999, PPP menolak mendukung Megawati dengan alasan dalam ajaran Islam perempuan tidak diperbolehkan menjadi pemimpin 
yang utama. Beberapa contoh peristiwa tersebut mengindikasikan partai-partai Islam ternyata bertindak lentur dari garis ideologi yang telah mereka tetapkan atau setidaknya yang telah menjadi persepsi publik.

Pada pemilu 2004, jumlah partai-partai berbasis Islam menurun menjadi hanya 7 partai. Hal itu disebabkan pemberlakuan UU No. 31 Tahun 2002 tentang Partai Politik dan UU No. 12 tahun 2012 tentang Pemilihan Umum, yang salah satunya menerapkan aturan tentang ambang batas parlemen (parliamentary threshold) untuk membatasi dan menyeleksi partai-partai yang hendak turut dalam pemilu. Di saat yang sama juga diberlakukan sistem pemilihan presiden dan kepala daerah secara langsung yang mendorong faktor popularitas figur mengungguli popularitas partai dalam pemilu. Mekanisme tersebut mendorong partai-partai untuk bekerja sama dan berkoalisi dalam mengusung kandidat presiden dan wakil presiden dan pasangan kepala daerah. Pada masa ini, partai-partai Islam belum mampu menawarkan figur pemimpin populer yang dapat memenangkan pemilihan presiden. Figur-figur politik seperti Hamzah Haz (PPP), Amien Rais (PAN), Abdurrahman Wahid (PKB) ternyata kalah elektabilitas dengan figur militer, Susilo Bambang Yudhoyono (SBY, Partai Demokrat). Kampanye politik berbasis media massa telah mengubah preferensi pemilih dari yang semula cenderung ditentukan oleh hubungan elite-massa menjadi ditentukan oleh popularitas figur di media massa. Figur-figur partai Islam yang masih mengandalkan modal politik tradisional belum mampu mengimbangi dinamika elektoral yang semakin beriringan dengan perkembangan teknologi.

Setelah pemilihan presiden 2004 dan 2009 dimenangkan oleh SBY secara berturut-turut, partaipartai berbasis Islam senantiasa menjadi pendukung loyal pemerintahan. Para pengamat cenderung menganalisis gejala tersebut sebagai pergeseran pola tindakan partai-partai berbasis Islam dari ideologis menjadi pragmatis (Permata 2008; Hasan 2009; Buehler 2009). Ketidakmampuan partai Islam menawarkan figur alternatif yang dapat bersaing pada ajang pemilihan presiden mendesak mereka untuk berkoalisi demi mendapatkan jatah kursi di pemerintahan. Sementara itu, mereka juga harus menyiasati pembiayaan partai yang semakin sulit. Pemberlakuan UU No. 2 tahun 2008 mengatur sumber finansial partai politik, yaitu iuran anggota, sumbangan yang sah menurut hukum, bantuan keuangan dari Anggaran Pendapatan dan Belanja Negara/Anggaran Pendapatan dan Belanja Daerah (APBN/APBD). Tetapi pada kenyataannya, sumber-sumber tersebut tidak mencukupi pembiayaan operasional partai, terlebih lagi jika melihat beban biaya kampanye yang semakin tinggi. Pada akhir 2008, belanja iklan partai politik mengalami kenaikan dari Rp.1,2 triliun menjadi Rp.2,2 triliun atau naik sekitar 66 persen. Sementara besaran subsidi negara terhadap partai politik terus mengalami penurunan (Ahmad \& Herdiansah 2013). Keadaan tersebut mendesak partai-partai untuk mencari sumber 
pendanaan alternatif, mulai dengan cara menarik potongan pendapatan anggotanya di parlemen hingga mencari celah dari proyek-proyek pemerintah. Karena itu, menempatkan kader di parlemen dan penguasaan kursi di kabinet menjadi kunci bagi partai untuk mempertahankan sumber-sumber finansial mereka (Mietzner 2007).

Cara partai menarik subsidi secara tidak langsung dari negara berdampak pada semakin tingginya praktik korupsi. Tidak sedikit kader dari partai-partai berbasis Islam yang dipenjara karena terlibat korupsi. Berdasarkan data Indonesian Corruption Watch (ICW) sepanjang 2002-2014, urutan partai politik yang kadernya paling banyak terlibat korupsi adalah (1) PDIP, (2) PAN, (3) Partai Golkar, (4) PKB, (5) PPP, (6) PKPI, (7) Partai Gerindra, (8) Partai Demokrat, (9) PBB, (10) Partai Hanura, dan (11) PKS (Republika.co.id 2014). Dari data tersebut, meskipun PKS menempati urutan terakhir, tetapi kasus korupsi yang dilakukan pimpinan partai pada 2013, Luthfi Hasan Ishaq, telah memperburuk citra partai yang dikenal bersih dan profesional. Faktafakta tersebut menyiratkan bahwa pada umumnya partai-partai berbasis Islam tidak memiliki perbedaan khas dalam hal moralitas dengan partai-partai yang bukan berbasis agama/umat. Keterlibatan kader-kader partai berbasis Islam dalam praktik korupsi justru memperkuat persepsi publik bahwa mereka hanya menjadikan simbol-simbol Islam dan keumatan sebagai instrumen kepentingan para elitenya.

Dengan anggapan bahwa partai-partai berbasis Islam telah terjebak pada pola tindakan pragmatis yang sejalan dengan penurunan perolehan suara di 2009, beberapa pengamat seperti Tanuwidjaja (2010) dan lembaga survey memprediksi partai-partai berbasis Islam tidak akan bertahan pada pemilu 2014. Instrumentalisasi simbol Islam dan keumatan yang tidak sejalan dengan kinerja partai Islam di pemerintahan dipandang sebagai penyebab menurunnya tingkat kepercayaan pemilih Muslim. Beberapa lembaga survei seperti Lembaga Survei Indonesia (LSI) dan Lembaga Survey Nasional (LSN) pada 2013 menyatakan bahwa PKS dan PBB diperkirakan tidak akan mampu menempatkan wakilnya di DPR karena rendahnya elektabilitas kedua partai tersebut (Dw.com 2013). Hasil survei dari LSI pada Januari 2014 memprediksi bahwa PKS hanya akan mendapatkan suara sebesar 2,2 persen, PBB memperoleh 0,7 persen, PKB berada pada rentang 4,1-5,1 persen, PPP meraih 3,6 persen, dan PAN di kisaran 1,7-3,2 persen (Kompas.com 2014).

Ketika tindakan-tindakan partai berbasis Islam yang mengutamakan penguasaan akses terhadap kekuasaan dan sumber daya negara cenderung dikonstruksikan sebagai pragmatisme, terdapat beberapa peristiwa yang menunjukkan indikasi yang berbeda. Contohnya kasus penentangan PKS terhadap kebijakan pemerintah selama periode 2004-2014, padahal ketika itu mereka merupakan anggota koalisi yang menjalankan pemerintahan. Pada kasus rencana kenaikan harga 
Bahan Bakar Minyak (BBM) di 2005, 2009, dan 2012 PKS menunjukkan sikap berseberangan dengan pemerintah walaupun pada akhirnya tidak dapat menolak kebijakan tersebut. Pada Desember 2009, PKS termasuk yang menginisiasi pembentukan panitia khusus kasus skandal Bank Century yang sempat memojokkan SBY dan Partai Demokrat. Pada Oktober 2011, sikap pembangkangan PKS terhadap SBY diganjar dengan dikuranginya satu menteri kursi menteri yaitu posisi Menteri Riset dan Teknologi yang dijabat oleh kader PKS, Suharna (Viva.co.id 2013).

Tindakan melawan arus yang dilakukan oleh PKS merupakan ekses dari dinamika yang terjadi pada internal partai itu. Sebagian kader PKS telah menunjukkan sikap kurang simpati terhadap kecenderungan elite yang membawa partai terlalu terseret pada pragmatisme politik. Pertarungan wacana yang berimbas pada dominasi kekuasaan antarfaksi menyebabkan keputusan-keputusan PKS dalam menyikapi situasi politik lebih dinamis (Munandar 2011). Adanya keinginan supaya PKS tidak terlalu melenceng dari prinsip dan nilai tarbiyah tindakan yang dimotivasi oleh faktor ideologis. Karena itu, asumsi bahwa mereka telah mengalami pergeseran pada pragmatisme dapat diperdebatkan.

Pasca pemilu 2014, suara partai Islam secara kolektif mengalami peningkatan. Prestasi tersebut merupakan buah dari kerja keras mereka ketika menghadapi pemilu. Kenaikan perolehan suara yang signifikan ditunjukkan oleh PKB yang memperoleh 9,04 persen suara. Peningkatan kinerja elektoral PKB tidak lepas dari keberhasilannya dalam membangun komunikasi politik dengan pesantren-pesantren, menggandeng tokoh-tokoh ulama, dan menghadirkan figur-figur populer (Ahmad Dhani, Jusuf Kalla, dan Rhoma Irama). Menjelang pemilu 2014, PPP menyuarakan slogan sebagai "Rumah Besar Umat Islam” untuk meyakinkan bahwa mereka masih konsisten membawa isu-isu keumatan di ranah politik. Sementara PKS yang tengah didera "tsunami politik" akibat penangkapan Luthfi Hasan Ishaq melakukan safari politik secara intens ke berbagai daerah. Semua tindakan itu menandakan bahwa partai Islam memiliki kemampuan organisasional dalam meningkatkan kinerja elektoral sekaligus menepis bahwa mereka sematamata mengandalkan simbol-simbol agama.

Pada periode 2014-2019, tidak semua partai berbasis Islam bergabung dengan pemerintah. PKS menyatakan tetap berada di luar pemerintahan. Sementara PAN meskipun akhirnya bergabung dalam pemerintahan, mereka justru bersikap seperti oposisi terhadap Jokowi-Jusuf Kalla. Partai berbasis Islam lainnya, PPP dan PKB, telah dulu berada di dalam gerbong pemerintah. Keputusan PKS berada di luar pemerintahan lebih disebabkan kuatnya keinginan para kader agar partai itu menarik diri dulu di pemerintahan sambil menguatkan kembali soliditas dan prinsip moral partainya. Keengganan kader-kadernya untuk mendukung Jokowi dan bekerja

164 | SGSIOGLLBAL : Jurnal Pemikiran dan Penelitian Sasiologi, Vol. I, №. Z, Juni 2017 
sama dengan PDIP juga menjadi alasan lain (Herdiansah 2016). Fakta-fakta tersebut menunjukkan bahwa pragmatisme yang diidentikkan dengan sikap mendukung pemerintahan merupakan pengertian yang tidak bisa dipertahankan lagi dan dimensi ideologi dalam tindakan mereka tidak sepenuhnya pupus.

\section{SIMPULAN}

Pragmatisme pada partai berbasis Islam perlu dipahami dari karakteristik organisasi partai yang bertujuan untuk meraih dominasi kekuasaan negara, mempengaruhi kebijakan publik, dan berorientasi pada kepentingan. Dalam upaya tersebut, partai Islam harus terlibat dalam kompetisi yang ketat dan melakukan berbagai macam strategi mulai dari kerja sama, kompromi, negosiasi, hingga friksi dengan institusi lain. Sebagai pelaku sosial, mereka tidak selalu dapat berpegangan pada panduan atau prinsip ideologi dalam menentukan tindakannya. Mengikut pendapat Giddens (1994), setiap pelaku memiliki pengetahuan dan informasi yang terbatas sehingga keputusan atau tindakannya bisa saja tidak sesuai dengan yang diharapkan. Tetapi, pelaku memiliki kemampuan refleksif sebagai mekanisme untuk melihat faktor sebab-akibat yang menyebabkan kegagalan atau keberhasilan tindakannya untuk dijadikan pengalaman di kemudian hari. Di sisi lain, partai Islam pun tidak dapat melepaskan diri dari simbol-simbol Islam dan atau aspirasi konstituennya, karena aspek tersebut merupakan identitas sekaligus modal politik yang esensial. Dengan demikian, dalam skema tindakan sosial partai Islam secara umum mengarah pada tindakan rasional yang dalam situasi tertentu lebih mengedepankan aspek pragmatis dan aspek ideologi pada aspek lainnya. Dinamika tindakan mereka ditentukan oleh penafsiran para pelaku terhadap keadaan dan situasi yang dihadapinya.

Artikel ini telah berupaya membedah pendekatan partai Islam dalam persaingan demokrasi di Indonesia melalui skema tindakan sosial. Namun, terdapat berbagai keterbatasan. Konsepkonsep yang digunakan masih bersifat elementer untuk menyederhanakan penjelasan. Pembahasan tindakan sosial kontemporer seperti dari Giddens dan Bourdieu kurang mendapatkan elaborasi. Karena itu, artikel ini memberikan peluang untuk pengembangan analisis lebih lanjut, misalnya bagaimana pendekatan pilihan rasional dapat juga digunakan untuk mendalami atau memberikan perspektif yang lain tentang dinamika partai Islam di Indonesia. 


\section{DAFTAR PUSTAKA}

Abed, Shukri B., Edy Kaufman, Shukri B. Abed, and Robert L. Rothstein. 1993. "Democracy and The Arab World." in Democracy, Peace, and Israeli-Palestinian Conflict. Colorado: Lynne Rienner Pub.

Ahmad, N. S. Y. and A. G. Herdiansah. 2013. "Ambiguity in Indonesian Cartelized Democracy: An Analysis on the Political Communication." African and Asian Studies 12(3).

Asayesh, Hosain, Adlina Ab Halim, and Sayedeh Nosrat Shojaei. 2011. Political Parties: Extent and Nature.

Ba-Yunus, I. and Hastings Donnan. 2002. "Ideological Dimension of Islam: Critical Paradigm." in Interpreting Islam. London: Sage Publication.

van Bruinessen, Martin. 2013. "Introduction: Contemporary Developments in Indonesian Islam and the 'Conservative Turn' of the Early Twenty-First Century." in Contemporary Developments in Indonesian Islam: Explaining the "Conservative Turn," edited by M. van Bruinessen. Singapore: Institute of Southeast Asian Studies.

Buehler, Michael. 2009. "Islam and Democracy in Indonesia." Insight Turkey 11(4):51.

Callahan, Gene. 2007. "Reconciling Weber and Mises on Understanding Human Action." American Journal of Economics and Sociology 66(5):889-99.

Cuff, E. C., W. W. Sharrock, and D. W. Francis. 2006. Perspectives in Sociology (5th Ed.). USA \& Canada: Routledge.

Dw.com. 2013. "Elektabilitas Partai-Partai Islam Menurun.” DW.COM. Retrieved June 29, 2017 (http://www.dw.com/id/elektabilitas-partai-partai-islam-menurun/a-17299436).

Hasan, Noorhaidi. 2008. "Reformasi, Religious Diversity, and Islamic Radicalism after Suharto." Journal of Indonesian Social Sciences and Humanities 1:23-51.

Hasan, Noorhaidi. 2009. "Islamist Party, Electoral Politics and Da'wa Mobilization among Youth: The Prosperous Justice Party (PKS) in Indonesia.” RSIS Working Paper 184.

Herdiansah, A. G. 2016. Rasionalitas PKS: Berdemokrasi Ala Tarbiyah. Bandung: Unpad Press.

Heywood, A. 2002. Politics. New York: Palgrave Macmillan.

Huckshorn, R. 1984. Political Parties in America. California: Brooks/Cole.

Inayatullah, Benni. 2009. "Partai Islam: Jalan Terjal Menuju Kemenangan.” in Indonesia 2008. Jakarta: The Indonesian Institute.

Jati, Wasisto Raharjo. 2013. "Radicalisn in the Perspective of Islamic-Populism: Trajectory of Political Islam in Indonesia." JOURNAL OF INDONESLAN ISLAM 7(2):268-287.

Kompas.com. 2014. "Partai Politik Berbasis Massa Islam Menjungkirbalikkan." Kompas.com.

Retrieved June 29, 2017

(http://nasional.kompas.com/read/2014/04/10/0622304/Partai.Politik.Berbasis.Massa.I slam.Menjungkirbalikkan.Survei).

Layder, Darek. 2006. Understanding Social Theory. London: Sage Publication.

Mashad, Dhurorudin. 2008. Akar konflik politik Islam di Indonesia. Jakarta: Pustaka Al-Kautsar.

Mietzner, Marcus. 2007. "Party Financing in Post-Suharto Indonesia: Between State Subsidies and Political Corruption." Contemporary Southeast Asia (Augustus):238-63. 
Mosheni, Payam and Clyde Wilcox. 2012. "Religion and Political Parties." in Routledge Handbook of Religion and Politics, vol. 13, edited by H. Jeff. London and New York: Routledge.

Munandar, Arief. 2011. "Antara Jemaah dan Partai Politik: Dinamika Habitus Kader Partai Keadilan Sejahtera Dalam Arena Politik Indonesia Pasca Pemilu 2004.” Universitas Indonesia.

Parsons, Talcott. 2005. "The Social System." in Contemporary Sociological Thought: Themes and Theories, edited by S. P. Hiler. Toronto: Canadian Scholars Press Inc.

Permata, Ahmad-Norma. 2008. "Islamist Party and Democratic Participation: Prosperous Justice Party (PKS) in Indonesia 1998-2006.” Westfalischen Wilhems-Universitat zu Munster, Munster.

Republika.co.id. 2014. "Komentar Demokrat Soal Indeks Korupsi ICW." Republika Online. Retrieved August 4, 2017 (http://republika.co.id/berita/nasional/politik/14/03/11/n29eso-komentar-demokratsoal-indeks-korupsi-icw).

Ritzer, George. 2005. Encyclopedia of Social Theory (Vol. II). edited by G. Ritzer. London: Sage Publication.

Sharrock, W. W., J. A. Hughes, and P. J. Martin. 2003. Understanding Modern Sociology. London: Sage Publication.

Tanuwidjaja, Sunny. 2010. "Political Islam and Islamic Parties in Indonesia: Critically Assessing the Evidence of Islam's Political Decline.” Contemporary Southeast Asia 32(1):29_ 49.

Tew, J. 2002. Social Theory, Power and Practice. New York: Palgrave Macmillan.

The Indonesian Institute. 2009. Indonesia 2008. Jakarta: The Indonesian Institute.

Tibi, Bassam. 2002. The Challenge of Fundamentalism: Political Islam and the New World Disorder. Berkeley: University of California Press.

Viva.co.id. 2013. "Gara-Gara Membangkang PKS Pernah Kehilangan Menristek, Kali Ini??" Viva.co.id. Retrieved August 4, 2017 (http://www.viva.co.id/berita/politik/420589-garagara-membangkang-pks-pernah-kehilangan-menristek-kali-ini).

Zeitlin, Irving M. 1994. Ideology and the Development of Sociological Theory. 5th ed. New Jersey: Prentice-Hall. 